\title{
Commuting patterns in Romania: Case study on Cluj County
}

József Benedek The study examines the spatial and economic

Babeș-Bolyai University,

Faculty of Geography,

Cluj-Napoca, Romania

E-mail:

jozsef.benedek@ubbcluj.ro

Iulia Hărănguș

Babeș-Bolyai University, Faculty of Geography,

Cluj-Napoca, Romania

E-mail:

iulia_harangus@yahoo.com

Titus Man

Babeș-Bolyai University, Faculty of Geography, Cluj-Napoca, Romania

E-mail:

titus.man@.ubbcluj.ro

\section{Keywords: \\ commuting to work, accessibility, economic development, \\ Cluj County}

characteristics of commuting to work in one of the most dynamic areas of Romania, Cluj County. Based on the 2011 census data, the study reveals a strong connection between accessibility and commuting intensity, while the urban network determines the spatial orientation of the dominant commuting flows. However, we found no significant relation between dynamic economic performance and commuting intensity.

\section{Introduction}

During socialism, apart from the Central and Eastern European (CEE) countries, a restricted and controlled spatial mobility regime was established in Romania, characterised by a low motorisation rate and migration (Sandu 1984). Under these circumstances, commuting was reduced to the closer suburban areas of the large urban agglomerations. While at the beginning of the transition period a large amount

Regional Statistics, Vol 6, No 2. 2016: 39-53; DOI: 10.15196/RS06203 
of the active population was employed in agriculture, the establishment of capitalist market structures determined a radical change in the structure of economic activities, which has influenced the intensity of the commuting. As a result of the post-socialist economic restructuration, the workplaces became spatially more concentrated. However, housing is still strongly dispersed, partly due to the inherited settlement network (more than 13,000 localities) and partly due to on-going suburbanization (Soaita 2013). There are two ways of overcoming this inconvenience: migration and commuting. The main advantage of commuting is related to the satisfaction of different preferences offered by the proximity between workplace and residential location The commute between rural residential locations and urban workplaces is seen as a striking form of urban-rural integration (Partridge et al. 2010). In addition, labour can easier follow the change on the workforce market. However, commuting may cause major difficulties due to pollution, traffic jams, and costs.

However, the Romanian population still has an overall low spatial mobility-both internal migration and commuting have a low intensity, even by regional comparison. Characterized by a strong economic growth, although the period 2002-2011 has witnessed an increase in the number of active population, the inner-county commuting has registered a small decrease (table 1). It means that the strong economic growth was not enough to trigger a significant increase in commuting. In fact, we have not found any significant correlation neither between the county level GDP per capita and the commuting rate nor between the county level economic growth rate and the commuting rate, contrary to the empirical findings of international literature (Östh and Lindgren 2012).

In parallel, both inter-county and international commuting have almost doubled. It implies that there is little change in commute over short distances, but - somehow surprisingly - an important change in both middle- and long-distance commutes. The strong spatial concentration of economic growth and reducing importance of political borders for labour mobility in trans-border regions in Romania explains the latest situations in the country, which is forcing people from peripheries to travel longer distances for work (Nagy 2012). However, overall the commuting rate in 2002 was only around $16.8 \%$ and approximately $21 \%$ in 2011 . This relative low growth of internal mobility is compensated by the strong international mobility of the Romanian population, with an estimated 2-3 billion Romanians being registered in different EU countries, mainly in Italy and Spain (Boboc et al. 2012). It means that more than $10 \%$ of the total population of Romania in 1992 has left the country, a particular situation in the present European context, which may explain the lower figures of internal mobility. 
Commuting categories in Romania

\begin{tabular}{c|c|c|c|c|c|c|c}
\hline \multirow{2}{*}{ Year } & \multirow{2}{*}{$\begin{array}{c}\text { Active } \\
\text { population }\end{array}$} & \multicolumn{2}{|c|}{$\begin{array}{c}\text { Workplace in other } \\
\text { localities of } \\
\text { the county }\end{array}$} & \multicolumn{2}{|c|}{$\begin{array}{c}\text { Workplace } \\
\text { in other county }\end{array}$} & \multicolumn{2}{c}{$\begin{array}{c}\text { Workplace } \\
\text { in other country }\end{array}$} \\
\cline { 3 - 8 } & & & $\%$ & & $\%$ & & $\%$ \\
\hline $2002^{\text {a) }}$ & $7,811,733$ & $1,000,798$ & 12.81 & 187,176 & 2.40 & 124,248 & 1.59 \\
$2011^{\text {b) }}$ & $8,507,759$ & $1,086,614$ & 12.77 & 470,963 & 5.53 & 247,270 & 2.91 \\
\hline
\end{tabular}

a) http://www.insse.ro/cms/files/RPL2002INS/vol2/tabele/t31(576-584).pdf

b) www.recensamantromania.ro/wp-content/uploads/2015/05/vol3_t33.xls

In this broader spatial and national context, the main aim of the paper is to analyse commuting in one of the economically wealthiest areas of Romania, Cluj County (NUTS-3), situated in the north-western part of Romania. We assume that commuting plays an important role in dynamic economics, and that economic development, accessibility, and commuting intensity are interconnected.

\section{Data and Methodology}

The study relies largely on data from 2011 census, which is the only source of data on commuting in Romania. For the general context, we compared commuting data on county level (județ in Romanian, corresponding to the Nomenclature of Territorial Units for Statistics (NUTS) 3 level), while the main part of the study focuses on commuting data at local level (towns and communes, corresponding to the NUTS 5 level). The focus is on spatial differentiation in commuting, therefore we extensively visualised the analysed results. In addition, we analysed the commuting characteristics recorded in the census data, which include the intensity and spatial orientation of commuting flows and economic profile of the commuters. Although we do not intend to go beyond the rather descriptive and exploratory nature of this study, we assume that commuting is strongly connected with economic development and accessibility. Concerning economic development, we provided only qualitative and descriptive information at the local level, while the GDP per capita is used for county level economic comparisons. For determining the accessibility of population to the urban centres of the examined county, particularly its main centre, Cluj-Napoca (Kolozsvár in Hungarian), we used the function of the GIS extension Network Analyst, 'Closest Facility'. Accordingly, for each locality, the shortest travel time was determined using the road and/or railway network. For the road network, we considered the average travel speed calculated in Rusu et al. (2013): $110 \mathrm{~km} / \mathrm{h}$ for highways, $70 \mathrm{~km} / \mathrm{h}$ national and European roads, $50 \mathrm{~km} / \mathrm{h}$ for county roads, and $30 \mathrm{~km} / \mathrm{h}$ for local roads. The average speed for train travels was determined through

Regional Statistics, Vol 6, No 2. 2016: 39-53; DOI: 10.15196/RS06203 
the function according to the travel times between the railway stations, as given in the official circulation program of the Romanian Railways.

\section{Spatial and economic characteristics of commuting in Cluj County}

In the general context described in section 1 , we expected to have a different situation for Cluj County, which registered one of the highest economic growth rates in Romania. This dynamic economic performance in the area and the improvements realised in the transport infrastructure have influenced active commuting in the county as compared to Romania. Despite the fact that the commuting rate of $21.8 \%$ is only slightly above the country average, a careful observation of the commuting categories in each county (Table 2) for 2011 provides a different picture: middle- and long-distance commuting (measured by the share of population with workplaces in other counties and the share of population with workplaces in other countries, respectively) are common for peripheries, while in the counties with highest economic performance, which is the case of Cluj County, short distance commuting (expressed as the share of population with workplaces in other localities of the county) is more significant. Particularly, we observed a short distance commuting rate of $17.5 \%$ for Cluj County, which is still low in international comparison but is well above the national average. The value of short-distance commuting places Cluj County in the 13th position (among 41 counties) compared to Romania, which is well below its economic position ( $4^{\text {th }}$ position in the GDP per capita ranking). It is due to the stronger spatial concentration of population in the county's centre, Cluj-Napoca, (comprising $66 \%$ of the county's population) and in its larger urban influence zone (comprising $75 \%$ of the county's population), which reduces the commuting intensity.

\section{Commuting categories in the Romanian counties (NUTS-3 units) in 201}

Table 2

\begin{tabular}{|c|c|c|c|c|c|c|c|c|}
\hline County & $\begin{array}{l}\text { Active } \\
\text { pop. }\end{array}$ & $\begin{array}{c}\text { Pop. } \\
\text { with } \\
\text { work- } \\
\text { place in } \\
\text { other } \\
\text { localities } \\
\text { of the } \\
\text { county }\end{array}$ & $\%$ & $\begin{array}{c}\text { Pop. } \\
\text { with } \\
\text { work- } \\
\text { place in } \\
\text { other } \\
\text { county }\end{array}$ & $\%$ & $\begin{array}{l}\text { Pop. } \\
\text { with } \\
\text { work- } \\
\text { place in } \\
\text { other } \\
\text { country }\end{array}$ & $\%$ & $\begin{array}{c}\text { Comm. } \\
\text { rate } \\
\%\end{array}$ \\
\hline Alba & 141,389 & 25,673 & 18.16 & 5,906 & 4.18 & 2,195 & 1.55 & 23.89 \\
\hline Arad & 176,087 & 37,544 & 21.32 & 5,328 & 3.03 & 3,865 & 2.19 & 26.54 \\
\hline Argeș & 283,772 & 67,113 & 23.65 & 10,924 & 3.85 & 3,513 & 1.24 & 28.74 \\
\hline Bacău & 269,136 & 32,297 & 12.00 & 9,038 & 3.36 & 11,686 & 4.34 & 19.70 \\
\hline Bihor & 240,521 & 47,933 & 19.93 & 4,553 & 1.89 & 4,482 & 1.86 & 23.68 \\
\hline Bistrița-Năsăud & 133,797 & 15,353 & 11.47 & 3,261 & 2.44 & 4,765 & 3.56 & 17.47 \\
\hline BotoȘani & 192,647 & 9,615 & 4.99 & 5,924 & 3.08 & 10,915 & 5.67 & 13.74 \\
\hline
\end{tabular}




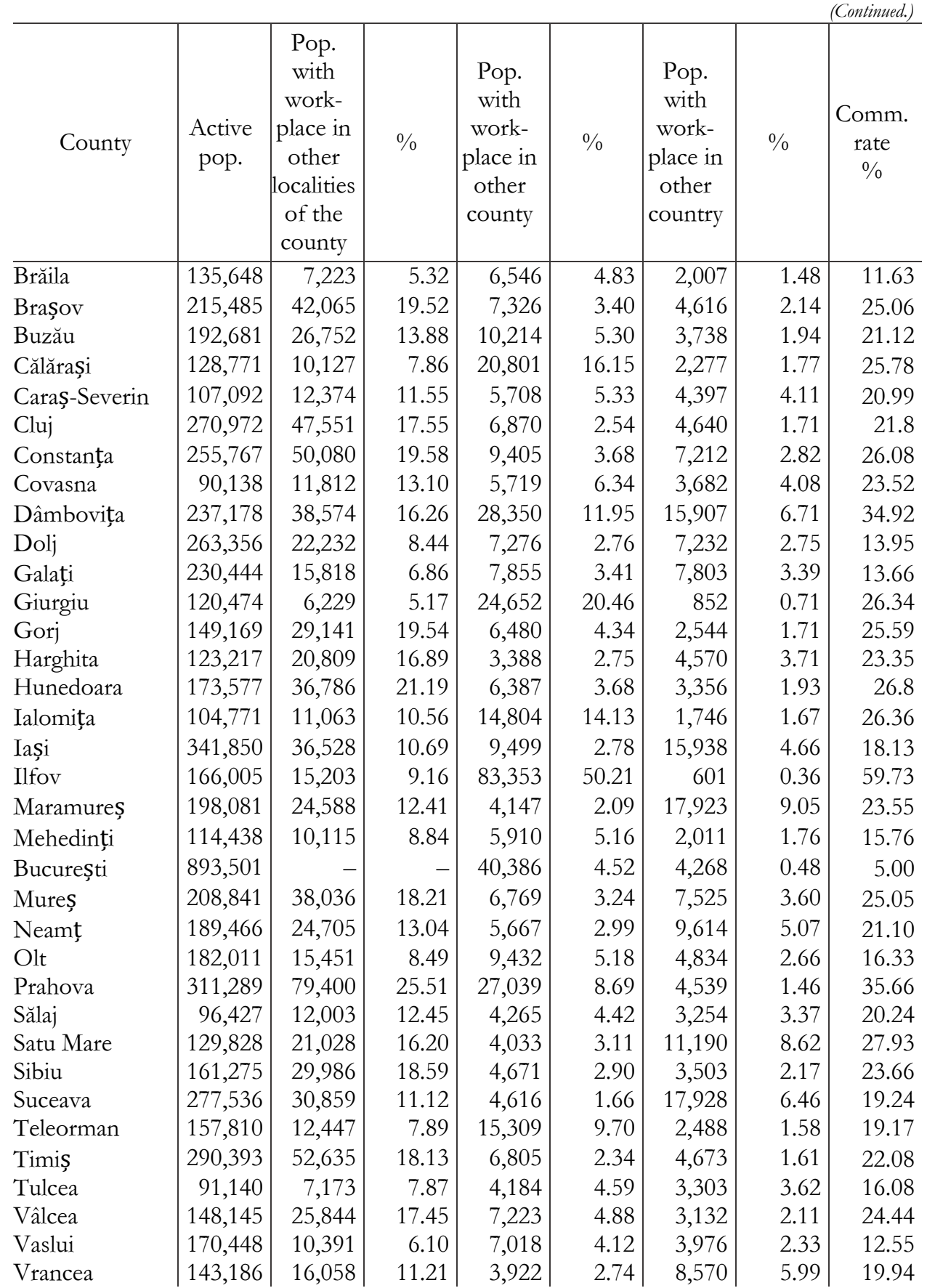

Source: Own compilation based on census data.

Regional Statistics, Vol 6, No 2. 2016: 39-53; DOI: 10.15196/RS06203 
The difference between absolute incoming and outgoing commuter numbers in Figure 1 illustrates the balance in commuting at the NUTS 5 level (cities and communes). The cities Cluj-Napoca, Dej, and the Jucu commune registered the highest positive balance. Both Cluj-Napoca and Dej underwent reindustrialization during the 2000s and witnessed the establishment of new industrial parks, and consequently became home to important industries. In addition, the counties have developed a strong service sector, based on their regionally important demographic size (Cluj-Napoca and Dej comprise 324,000 and 31,000 inhabitants, respectively). The situation of Jucu (4,300 inhabitants) is explained by the spatial distribution of the new economy, which transformed the commune. As a result, Jucu became the only rural location to be selected for the development of one of the six new industrial parks planned for the county. The commune witnessed the launch of Tetarom III in 2008, generating around 2000 new jobs (Benedek et co. 2013). Generally, all cities have shown a positive balance, with exception of Gherla (21,000 inhabitants) and Turda (48,000 inhabitants), which are situated in the influence zone of Dej and Cluj-Napoca.

\section{The spatial distribution of absolute commuting balance}

Figure 1

Difference of the number of incoming and outgoing commuters for work

$(-5,021)-(-101)$

$(-100)-100$

$100-17,845$

Settlement network

County capital

- Municipality

- Town

- Commune centre

5 Limit is territorial administrative unit

European road

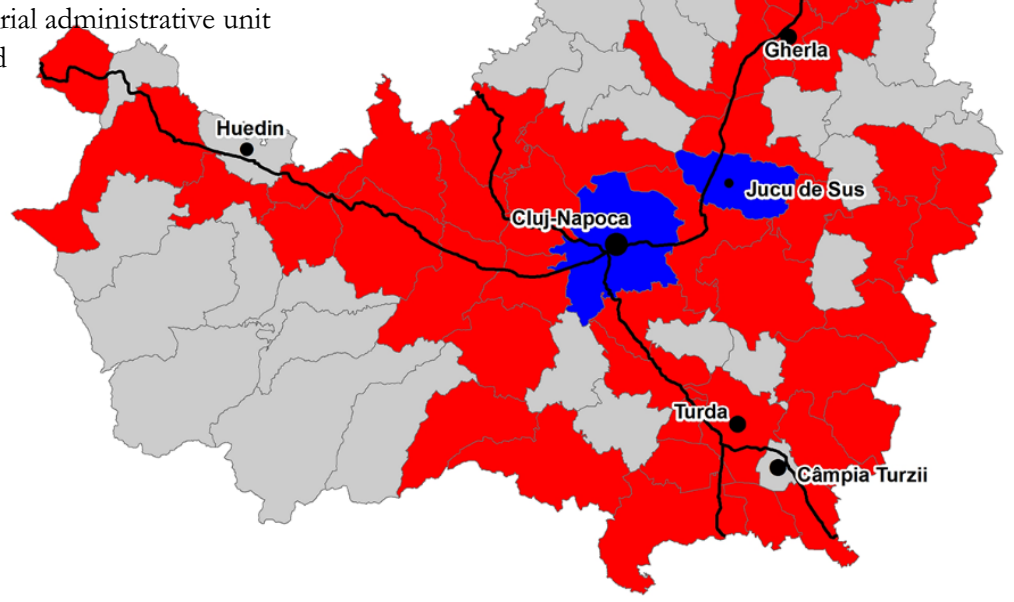

Source: Own draft, based on 2011 census data. 
On the opposite site, the suburban commune Florești has the highest negative balance. Although its population growth is impressive (the highest in Romania, reaching 21,000 inhabitants in 2011), it has not been successful in developing employment opportunities. These rural communes have become a dormitory area of Cluj-Napoca. High values of negative commuting balance are also registered by other suburban communes of Cluj-Napoca (Baciu, Apahida, and Aghireș) and two cities (Gherla and Turda). These cities have good transport connectivity, and therefore provide opportunities for commuting to the main concentration areas of the workforce represented by Cluj-Napoca, Dej, and Jucu.

The high negative commuting balance of large rural areas (indicated in orange in Figure 1) might be related to their high accessibility levels, while the three compact peripheral rural areas (shown in green in Figure 1) are rather indifferent to commuting, registering low values of absolute commuting (between 100 and -100 commuters).

\section{The spatial distribution of incoming commuters}

Figure 2

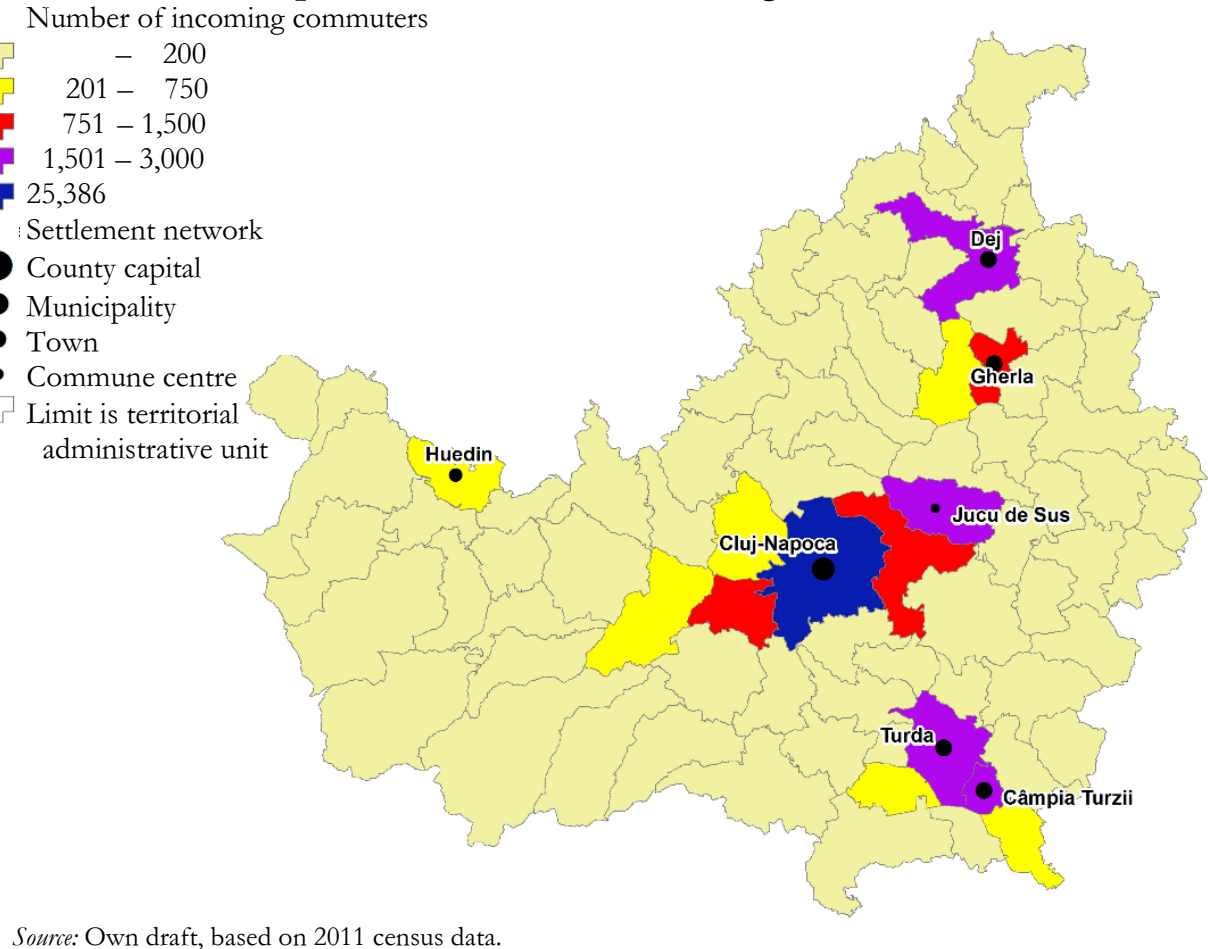

Figures 2 and 3 depict the two main components of the commuting balance: the incoming and outgoing commuting, in absolute numbers. Cluj-Napoca is the leading destination for incoming commuters, attracting around 25,000 commuters daily, followed by Dej (2,800 commuters), Jucu (2,200 commuters), and the urban

Regional Statistics, Vol 6, No 2. 2016: 39-53; DOI: 10.15196/RS06203 
agglomeration formed by the neighbouring cities of Turda and Câmpia Turzii (4,400 commuters together). In fact, all the cities are important attractors of incoming commuters; in addition, the suburban communes like Florești (1,500 commuters, more than cities like Gherla or Huedin), Apahida, and Baciu all attracting an important number of commuters.

The picture is slightly different concerning the outgoing commuters. Cluj-Napoca leads with around 7,500 outgoing commuters; closely followed by Florești $(6,500)$, and at some distance by Turda (3,700); Apahida and Baciu (each with 2,600 commuters); and Dej, Gherla, and Câmpia Turzii (each with around 2,000 commuters). It implies that we cannot define the dominant unidirectional commuting flows; they are rather oriented in both directions inside the economically active areas like the urban agglomerations of Cluj (including the three suburban communes), Turda-Câmpia Turzii, Dej, and Gherla. The only exceptions are the Jucu and Aghireșu communes. While incoming commuters flow is dominant in Jucu due to its industrial park, the outgoing commuters flow is dominant in Aghireșu. The overall findings reflect the profound changes determined by the intense post-socialist socioeconomic transformation, typical commuting groups including the suburbanized social middle-class groups around the Cluj County, well-educated employees commuting from cities to rural areas, or well-qualified workers commuting to the new industrial parks from Cluj, Jucu, or Dej.

Figure 3

\section{The spatial distribution of outgoing commuters}

Number of outgoing commuters

$36-300$

$301-600$

$601-1,500$

$1,501-3,500$

$3,501-7,541$

Settlement network

County capital

- Municipality

- Town

- Commune centre

Limit of territorial administrative unit

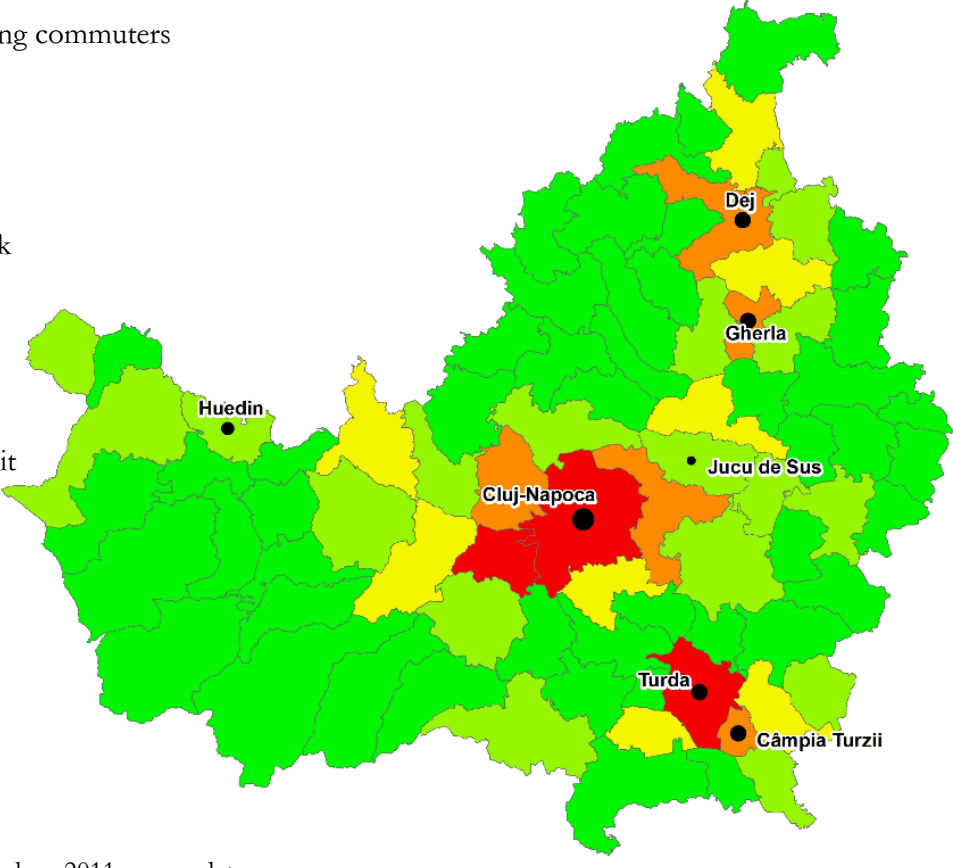

Source: Own draft, based on 2011 census data.

Regional Statistics, Vol 6, No 2. 2016: 39-53; DOI: 10.15196/RS06203 
Figure 4 presents the spatial distribution of relative commuting. It implies that the share of commuters form the total number of employees in each town and commune. The scenario differs in details when compared to the absolute commuting. ClujNapoca, with the largest number of absolute commuters, has the lowest commuting rate due to its large employee base, totalling to 143,000 employees, which represents $53 \%$ of the total number of employees in Cluj County. This situation and explanation is also valid for the other two major commuting areas represented by Dej and TurdaCâmpia Turzii.

Figure 4

\section{Relative commuting in Cluj County}

The percentage of commuters from employees

$$
-15
$$

$15-25$

$25-35$

$35-45$

$45-60$

Settlement network

County capital

- Municipality

- Town

- Commune centre

$\checkmark$ Limit of territorial administrative unit

Source: Own draft, based on 2011 census data.

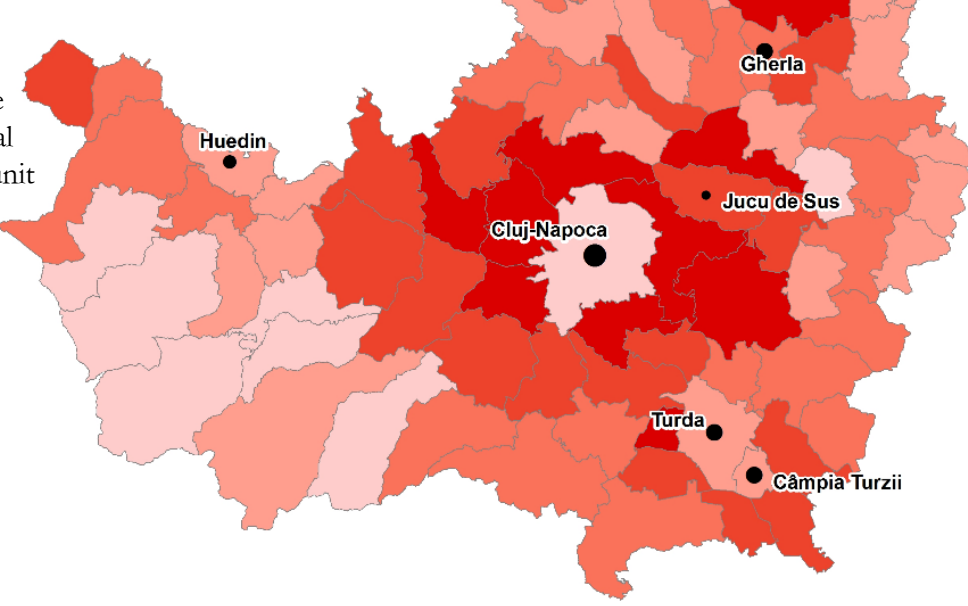

Unlike in the case of relative commuting, the role of Cluj-Napoca as a major organiser of the commuting flows in the county is expressed by the disposal of two commuting belts around it, with the rate of commuting exceeding $45 \%$, respective between $35-45 \%$, where the intensity of commuting decreases with distance and accessibility. The northern and southern parts of the county, the city of Dej and the urban agglomeration Turda-Câmpia Turzii, respectively, are playing a similar role, but on a lower scale and intensity.

Owing to the radical shift in the economic structure of the county from agriculture and industry towards services, the service activities are attracting a large number of commuters. Commuting in industry still plays an important role as a result of the

Regional Statistics, Vol 6, No 2. 2016: 39-53; DOI: 10.15196/RS06203 
reindustrialisation in the 2000s, while commuting in agriculture shows low values in the county, with the notable exception of the western, mountainous part of the county (Figure 5). The urban centre of this area, Huedin (9,300 inhabitants), has one of the largest primary sector $(5 \%)$ among the cities in Cluj county, overtaken only by Dej $(6 \%)$.

Figure 5

\section{The spatial distribution of commuters in primary activities}

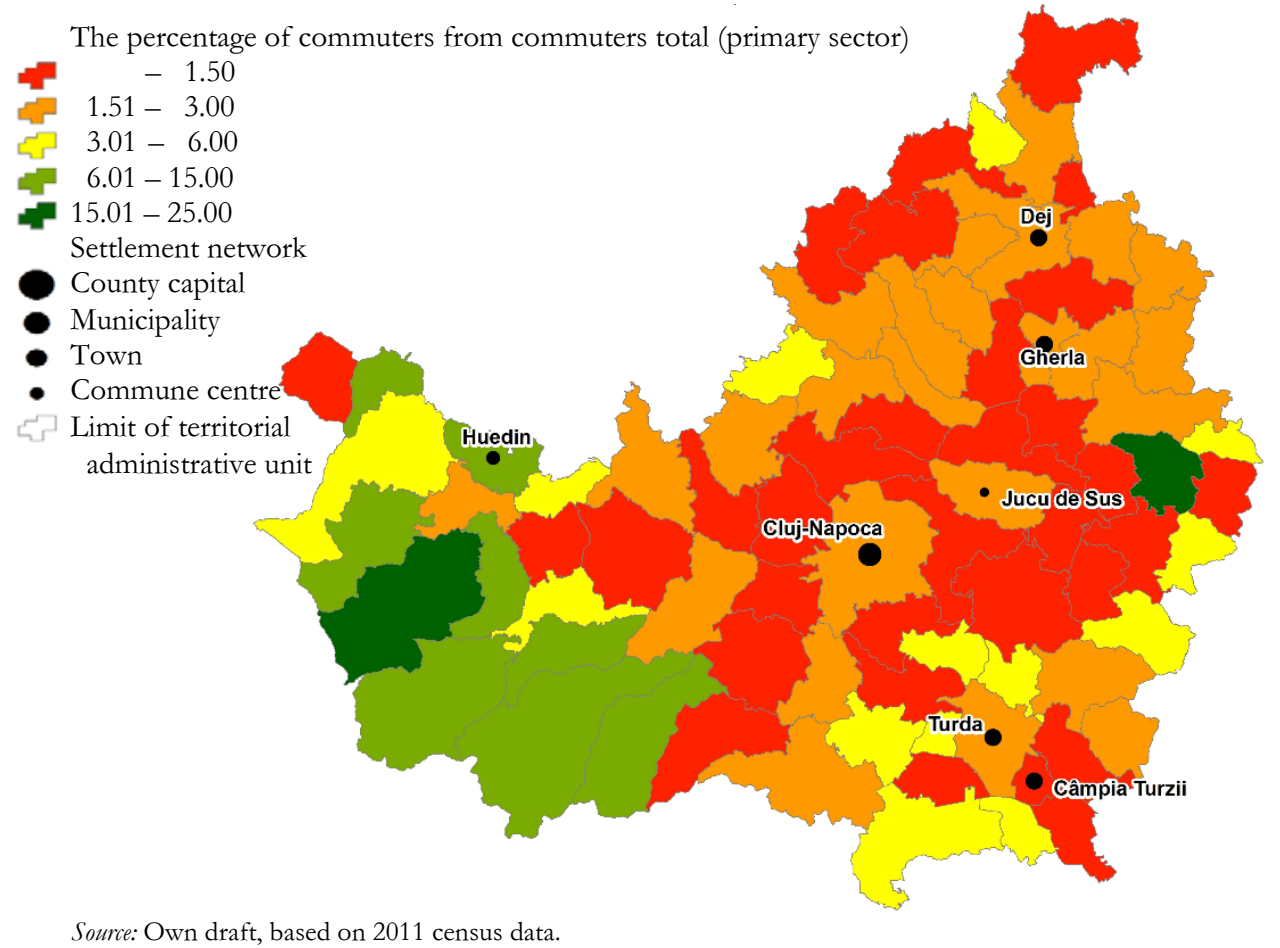

Figures 6 and 7 reveal that the specialisation of commuters is highly adapted to the economic profile of the main commuter attracting areas. Therefore, commuters in the larger suburban zone of Cluj-Napoca have workplaces engaged in different service activities, corresponding to the high share of services in the economic profile of the city. Annex 1 provides additional information on the professional profile of commuters compared to the professional categories of the attractor localities. Approximately, $75 \%$ of the workforce in Cluj-Napoca is engaged in the services sector, with IT, retail trade, education, and health services being the largest employers of this sector. The people commuting to Cluj-Napoca have the largest share of employees engaged in retail, construction, and transportation, while the employees in IT, education, and health services have smaller proportions in comparison to Cluj, reflecting the lower education and status of the commuters. 


\section{The spatial distribution of commuters in industry}

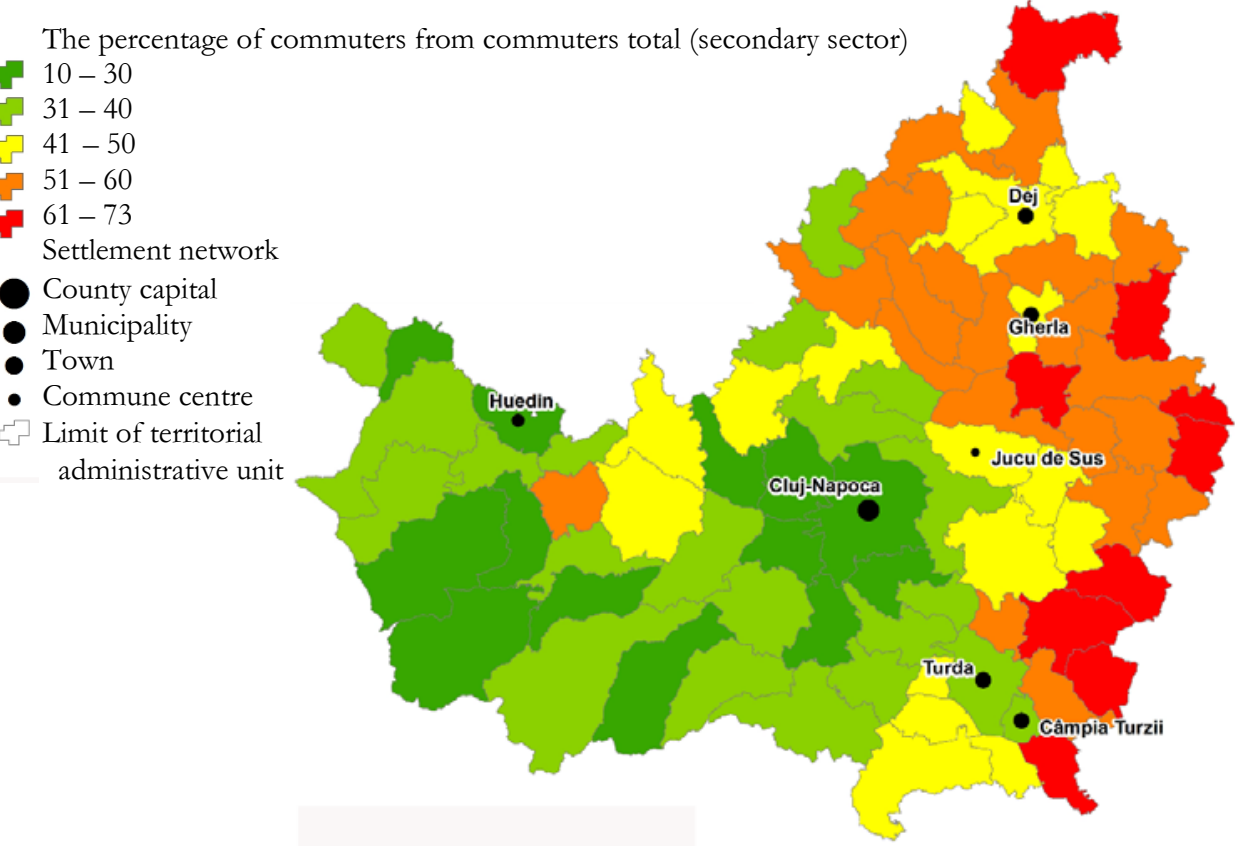

Source: Own draft, based on 2011 census data.

Commuters in the northern and southern part of the county, attracted by the labour market of the urban centres, Dej, Gherla, and Turda-Câmpia Turzii, are mainly occupied in industrial activities, according to the high industrial profile of these cities. Annex 1 also provides detailed data on this aspect. For example, in the case of commuters to Gherla, the largest group (20\%) of commuters consists of employees engaged in the manufacture of wood products. In the case of commuters to Câmpia Turzii, employees engaged in the metal manufacture activity represent the largest group (14\%), while for Dej and Turda we have the same economic profile of commuters as in the case of Cluj-Napoca. Câmpia Turzii belongs to the few cities in Romania where the largest amount of local workforce is employed in the industrial sector $(50 \%)$ due to the small demographical size of the city (22,000 inhabitants) and the dominant position of a single large industrial factory in the local labour market. 
The spatial distribution of commuters in the service sector

Figure 7

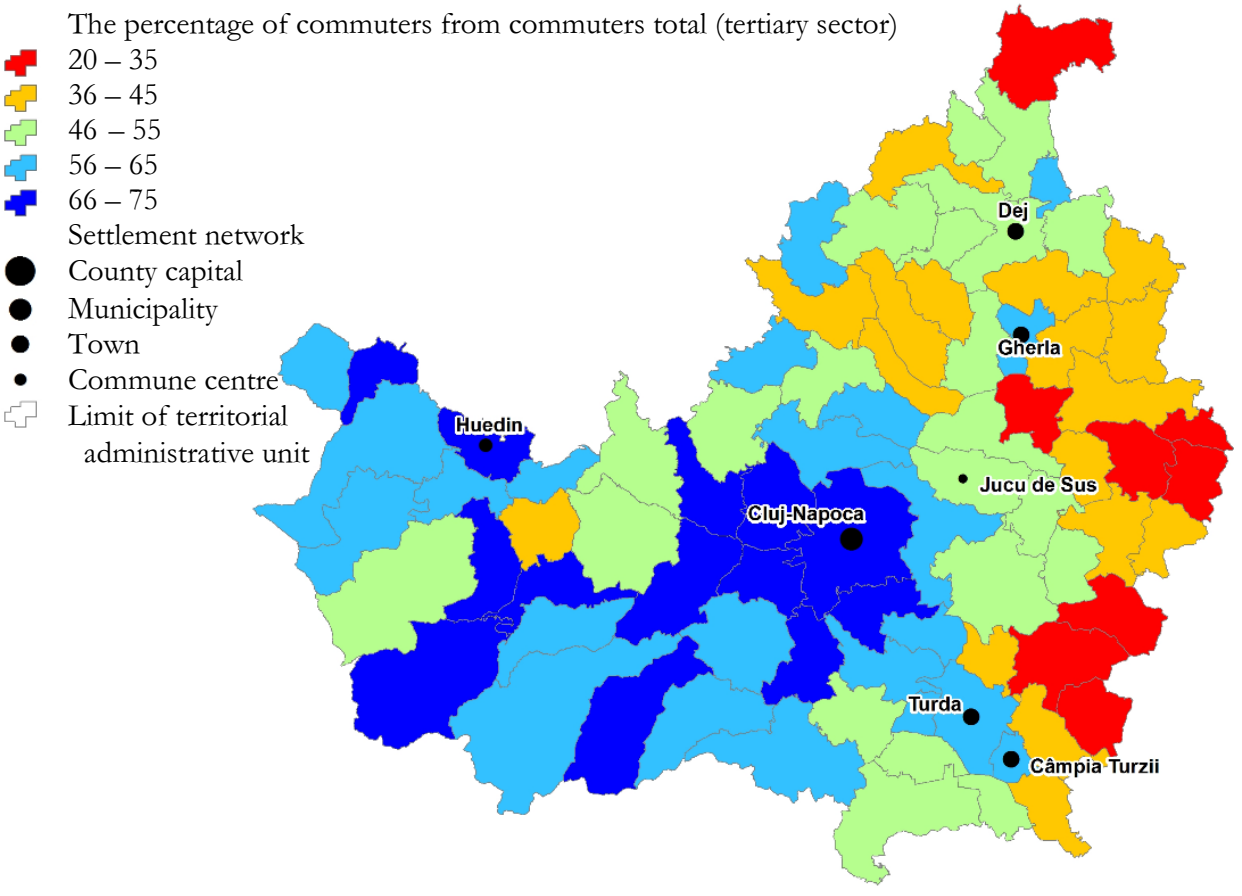

Source: Own draft, based on 2011 census data.

Figure 8 presents arguments in favour of the connection between accessibility and commuting intensity. The area delimited by the isochrone of 30 minutes travel time registers the highest commuting intensity. In addition, we have three cases where the isochrones of 30-50 minutes do not represent an obstacle for intensive commuting to Cluj-Napoca. It might be attributed to the fact that, during the post-socialist transition, the means of commuting have changed. There is a shift from bus and train to private car, which may lead to an increase in the commuting distance.

The same figure reveals that the Metropolitan Zone of Cluj-Napoca, created as an association with an aim to promote integrated spatial planning and development, functions like a highly integrated labour market, whose limits can probably be even extended based on commuting intensity and accessibility. 


\section{Accessibility and commuting oriented to Cluj-Napoca}

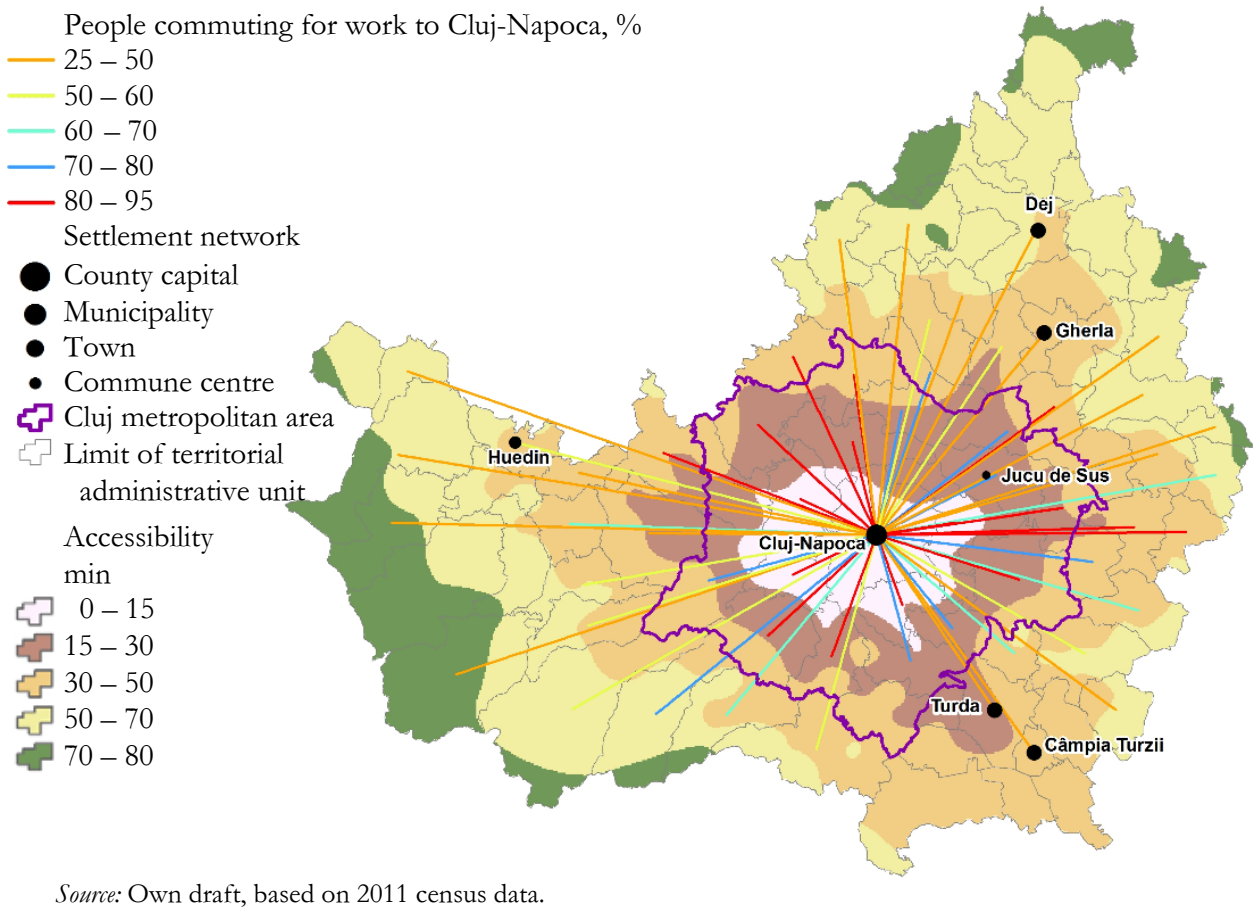

Source: Own draft, based on 2011 census data.

When considering the relationship between accessibility and commuting to all cities of the county, three secondary commuting systems around Turda-Câmpia Turzii, Gherla-Dej, and Huedin became evident (Figure 9). Intensive commuting could be identified only in the cases of Cluj-Napoca and Dej, while long-distance commuting was present in case of Huedin and Gherla (isochrones of 35-45 minutes), revealing their particular role as local workplace suppliers and in geographical space configuration. Figure 9 displays the particular role played by the commune of Jucu to attract significant commuting flows from both the suburban area of Cluj and TurdaCâmpia Turzii. As a general picture, Figure 9 reflects the delimitation of the urban influence zones in relation to commuting intensity and accessibility. Facilitated by short distance and the good accessibility, the overlapping tendencies between the commuter zone of Cluj-Napoca and that of Turda are evident, while longer distance has favoured the maintenance of the local urban influence zones in the cases of Huedin and Gherla. The peripheral areas situated between the isochrones of 45-65 minutes show that an insignificant amount of commuting has been left outside the functional urban labour markets. It can be viewed as the threshold where migration decisions may prevail to commuting.

Regional Statistics, Vol 6, No 2. 2016: 39-53; DOI: 10.15196/RS06203 


\section{Accessibility and commuting oriented to Cluj-Napoca}

The percentage of people commuting for work to towns

$25-50$
$50-60$
$-60-70$
$-70-80$
$-80-95$

Settlement network

County capital

- Municipality

- Town

- Commune centre

c5luj metropolitan area

Limit of territorial

administrative unit

Accessibility to towns

$\min$

가 $0-15$

$15-25$

$25-35$

$35-45$

$45-65$

Source: Own draft, based on 2011 census data.

\section{Conclusions}

The study has produced some interesting results on present day commuting to work in a dynamic economic environment, illustrated through the Cluj County. First, although we were unable to measure the economic output at a local level accurately, the county level comparison of GDP per capita and commuting rate did not reveal any significant correlation between commuting and economic development, contrary to the findings in international literature. We have explained this particular situation in the context of intensive international migration. Second, we found a similar situation at the county level. In this context, we were able to provide qualitative information on the location of new industrial parks in relation with the establishment of spatial commuting attractors. We also presented new facts on the relationship between accessibility and commuting, the economic profile of commuters, and the important role played by settlement networks in the spatial orientation of commuting flows. 


\section{REFERENCES}

BenedeK, J.-CRISTEA, M.-LANG, T. (2013) Fallstudienbericht Rumänien In: Müller, A.Plöger, J. (eds.): Wieder erstarkte Städte: Strategien, Rahmenbedingungen und Ansätze der Regenerierung in europäischen Groß- und Mittelstädten pp. 16-30., (Werkstatt: Praxis, Heft 82)., Bundesministerium für Verkehr, Bau und Stadtentwicklung, Bundesamt für Bauwesen und Raumordnung, Berlin.

Boboc, C.-VAsiLE, V.-TodosE, D. (2012) Vulnerabilities associated to migration trajectories from Romania to EU countries Procedia - Social and Behavioral Sciences 62: 352-359.

NAgY, E. (2012) The Situation of the Workforce Market in the Southern Part of the Romanian-Hungarian Border Studia Universitatis „Babeş - Bolyai“, Series Geographia 57 (2): 153-160.

ÖSTH, J.-LINDGREN, U. (2012): Do changes in GDP influence commuting distances? A study of Swedish commuting patterns between 1990 and 2006 Tijdschrift voor Economische en Sociale Geografie 103 (4): 443-456.

PARTRIDGe, M. D.-Ali, K.-OlfERT, M., R. (2010) Rural-to-urban commuting: three degrees of integration Growth and Change 41 (2): 303-335.

RECENSĂMÂNTUL POPULAȚIEI ŞI AL LOCUINȚELOR (2011) Clasificarea activităților din economia naţională Bucureşti.

Rusu, R.-Man, T.-Moldovan, C. (2013): The GIS-Based Road Distance and Time Connectivity Index of the Settlements within the West Region of Romania Studia Geographia 58 (1): 141-150.

SANDU, D. (1984): Fluxurile de migrație în România Editura Academiei, București.

SoAITA, A., M. (2013): Romanian suburban housing: home improvement through ownerbuilding Urban Studies 50 (10): 2084-2101.

\section{WEB REFERENCES}

http://www.insse.ro/cms/files/RPL2002INS/vol2/tabele/t31(576-584).pdf www.recensamantromania.ro/wp-content/uploads/2015/05/vol3_t33.xls

Regional Statistics, Vol 6, No 2. 2016: 39-53; DOI: 10.15196/RS06203 